\title{
MARINE MONITORING ALONG THE EASTERN COASTAL AREA OF THE ISLAND OF LESVOS, GREECE DURING 2004 IN THE FRAMEWORK OF MEDPOL III
}

\author{
M. ALOUPI ${ }^{1, *}$ \\ M.O. ANGELIDIS ${ }^{1}$ \\ A. GABRIEL ${ }^{1}$ \\ M. KARANTANELLI ${ }^{2}$ \\ M. KOULOUSARIS ${ }^{1}$ \\ A. NIKOLAOU ${ }^{2}$ \\ A. PETSAS ${ }^{1}$ \\ G. TSIRTSIS ${ }^{2}$ \\ M. VAGI ${ }^{2}$ \\ F. VLATSIOTOU ${ }^{1}$
}

Received: 13/03/06

Accepted: 28/06/06

\author{
${ }^{1}$ Department of Environmental Studies, \\ University of the Aegean, \\ University Hill, 81100 Mytilini, Greece \\ ${ }^{2}$ Department of Marine Sciences, \\ University of the Aegean, \\ University Hill, 81100 Mytilini, Greece
}

\begin{abstract}
The present survey was carried out in the framework of MEDPOL Phase III (2004 - 2006), aiming to provide recent information for the long-term monitoring of pollution trends in selected susceptible marine environments along the Mediterranean coastline. Information was collected from a network of four stations spaced out along the eastern coast of the Island of Lesvos, Greece, including a high risk station near the harbour of the city of Mytilini. Pollutants in abiotic components of the marine environment (seawater, sediment) as well as in selected marine organisms ( $M$. barbatus and $B$. boops) were measured. It was found that there is no evidence of substantial pollution of the marine environment (seawater, sediment and fish) with respect to the pollutants measured. However, it was shown that although the uncontrolled discharge of untreated effluents has been reduced since the beginning of the operation of the Mytilini sewage treatment plant in 2001 , sediments near the harbour of the city still carry increased loads of metals of anthropogenic origin. Furthermore, the small quantity of untreated sewerage that still flows out in the harbour of the city seems to affect water quality, since a higher mesotrophic character with eutrophic trends was observed in the area.
\end{abstract}

KEYWORDS: MEDPOL Phase III, Aegean Sea, nutrients, metals, polyaromatic hydrocarbons, halogenated hydrocarbons.

\section{INTRODUCTION}

Eastern Mediterranean and the Hellenic seas in particular, are recognized among the most oligotrophic areas in the world (Ignatiades et al., 2002). Despite of this characteristic, eutrophication phenomena and pollution problems are frequently encountered in coastal waters of the Aegean and the lonian Seas, mainly due to by-products of anthropogenic activities in the watershed, including urban, industrial effluents and agricultural runoff (Scoullos, 1979; Angelidis et al.,1980; Voutsinou-Taliadouri, 1982; Varnavas et al., 1984; 1985; Boboti et al., 1985; Angelidis and Grimanis, 1989; Pagou and Ignatiades, 1990; Dassenakis et al.,1996; Tsirtsis and Karydis, 1998a; Angelidis and Aloupi, 2000; Aloupi and Angelidis 2001a; 2001b; Arhonditsis et al., 2003). Trying to compromise between the needs for economic growth and conservation of the environment, integrated coastal management 
schemes have to be developed, based both on the scientific knowledge of the natural environment and the social and economic priorities.

The assessment of coastal water quality has been based on a large number of methods differing in (a) the selection of variables, (b) the parametric or non-parametric character of the statistical method applied, (c) the method of data preprocessing and (d) the univariate or multivariate statistical approach (Karydis, 2001). A number of these methodologies has been already applied on coastal areas of the Aegean, aiming at the assessment of quality of the seawater, in local (Karydis, 1992; 1994; Friligos et al., 1994; Karydis and Tsirtsis, 1996) or regional (Tsirtsis and Karydis, 1998b; 1999) scales. Furthermore, sediments are also regularly used in surveys for the presence and/or accumulation of pollutants, either toxic metals or persistent organic compounds, in the marine environment since (a) they act as a sink of anthropogenic contamination, (b) they contain a historical record of physicochemical conditions and contamination, (c) their physicochemical environment allows particle-bound constituents to be transformed into potentially more toxic forms and (d) under changing environmental conditions they can release their contaminant loads back to the water column (Horowitz, 1991). In addition to abiotic environmental compartments, living organisms are often included in monitoring schemes in order to provide assurance of the quality of marine foodstuffs with respect to human health, as well as with an evaluation of trends over time in pollutant levels, especially in relation to the efficiency of control measures (FAO/UNEP, 1994). In any case, the efficiency of the various approaches to reveal spatial or temporal trends seems to be related to the availability and quality of field data. Moreover, the development and application of integrated coastal management schemes impose the need for the collection of long-term monitoring data from the natural environment to be combined and compared with observed long-term trends of the socioeconomic environment of coastal areas. MEDPOL, the environmental assessment component of the Mediterranean Action Plan, currently in Phase III (2004 - 2006), is a programme aiming to the long-term monitoring of pollution trends in selected susceptible marine environments along the Mediterranean coastline. A part of this programme is carried out in hellenic coastal waters including the Strait of Mytilini, the coastal area between the island of Lesvos, Greece and Asia Minor. In the present work recent information collected at the Strait of Mytilini is presented, related to the concentration of pollutants in abiotic components of the marine environment (seawater, sediment) as well as in selected marine organisms ( $M$. barbatus and B. boops). A preliminary assessment of the quality of the marine costal environment is also attempted.

\section{MATERIALS AND METHODS}

Information was collected from a network of four stations, including a high risk station near the port of Mytilini (GRE51) influenced by untreated sewage effluents (Karadanelli et al., 1992; Tsirtsis and Karydis, 1998) and three reference stations (GRE52 - GRE54), spaced out along the eastern coastal area of the Island of Lesvos (Figure 1). Two sampling cruises were carried out in July and October 2004. Seawater samples were analysed for nutrients and chlorophylla, whereas polyaromatic hydrocarbons were only measured in samples collected from the high risk station (GRE51). Basic geochemical parameters as granulometric composition, content in organic carbon, calcium carbonate and $\mathrm{Fe}$, metals ( $\mathrm{Cd}, \mathrm{Cr}, \mathrm{Cu}, \mathrm{Hg}, \mathrm{Mn}, \mathrm{Pb}$ and $\mathrm{Zn}$ ), polyaromatic and halogenated hydrocarbons were determined in sediment samples. Metals, polyaromatic and halogenated hydrocarbons were also measured in one pooled sample (of 10 individuals) of flesh for each fish species.

Phosphate, nitrate, nitrite and silicate analyses were carried out spectrophotometrically according to Parsons et al. (1984) and ammonia by the method proposed by Liddicoat et al. (1974). Chlorophyll-a was extracted in $90 \%$ acetone and measured fluorometrically (Neveux and Panouse, 1987). 


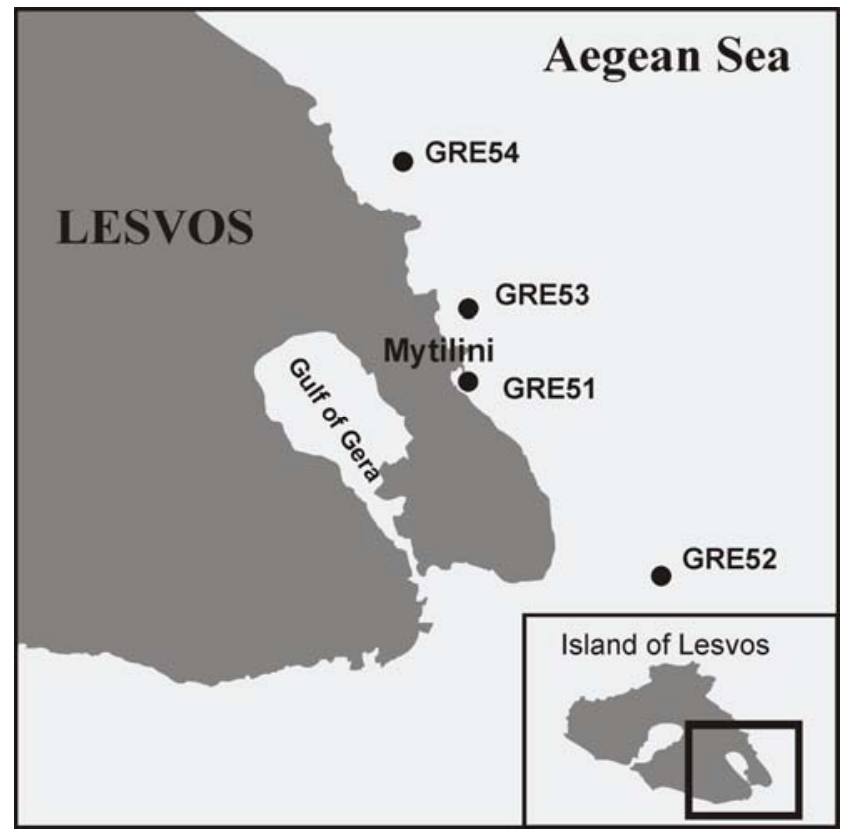

Figure 1. Location of monitoring stations along the eastern coast of the island of Lesvos, Strait of Mytilini

Sediment analyses for basic geochemical parameters and metal contents were performed according to the methods described by Loring and Rantala (1992), whereas the fish flesh samples were analysed for metal concentrations after digestion with a mixture of $\mathrm{HNO}_{3} / \mathrm{H}_{2} \mathrm{O}_{2}$ in tightly closed Teflon tubes and subsequent heating on a hot plate. Metal concentrations in both sediment and biota samples were measured in a Perkin Elmer 5100 ZL Atomic Absorption Spectrometer, equipped with a Zeeman background corrector. The choice of the appropriate technique, either Flame or Electrothermal (Graphite Furnace) AAS, was made according to the metal levels. Quality control of the analytical methods used in metal determinations was performed by analysis of the Certified Reference Materials BCSS-1, marine sediment, certified by NRCC and CRM 278, mussel tissue, certified by BCR (Table 1). Halogenated hydrocarbons were extracted with hexane from sediment and fish flesh samples. The extraction was carried out in an ultrasonic bath, while sodium sulphate was added to the samples to enhance extraction efficiency and to remove the residual moisture of the samples. The procedure was repeated twice. The extracts were separated by centrifugation, pooled and condensed to a small volume. The determination of halogenated hydrocarbons was made by Gas Chromatography, in a Hewlett Packard 5890 Series II gas chromatograph equipped with an Electron Capture Detector (ECD).

The determination of polyaromatic hydrocarbons in seawater, sediment and fish flesh samples was made by extraction with appropriate solvents and measurement by GC/MS, according to the method proposed by Nikolaou et al. (2004) with some modifications. Seawater sample pretreatment included the sequential extraction (in presence of $\mathrm{Na}_{2} \mathrm{SO}_{4}$ ) by $\mathrm{CH}_{2} \mathrm{Cl}_{2}$ and $\mathrm{C}_{5} \mathrm{H}_{12}$, condensation of the pooled extracts to dryness in an ultrasonic bath, and recovery of the residue by $\mathrm{CH}_{2} \mathrm{Cl}_{2}$. A similar procedure was used for the pretreatment of the solid substrates, apart from using a mixture of $\mathrm{CH}_{3} \mathrm{OH} / \mathrm{CH}_{2} \mathrm{Cl}_{2}$ in the first step of the extraction process. The analysis of the extracts was carried out in a Hewlett Packard 5890 Series II gas chromatograph connected to a Hewlett Packard HP5971 MSD mass spectrometer. 
Table 1. Certified and measured values (average of 3 replications) of the Certified Reference Materials BCSS-1, marine sediment and CRM 278, mussel tissue

\begin{tabular}{|lcccc|}
\hline & \multicolumn{2}{c}{ BCSS-1 } & \multicolumn{2}{c|}{ CRM 278 } \\
\hline & $\begin{array}{c}\text { Certified } \\
\text { value }\end{array}$ & $\begin{array}{c}\text { Measured value } \\
(\mathrm{n}=3)\end{array}$ & Certified value & $\begin{array}{c}\text { Measured value } \\
(\mathrm{n}=3)\end{array}$ \\
\hline $\mathrm{Cd}\left(\mathrm{mg} \mathrm{kg}^{-1}\right)$ & $0.25 \pm 0.04$ & $0.28 \pm 0.01$ & $0.34 \pm 0.02$ & $0.36 \pm 0.02$ \\
$\mathrm{Cr}\left(\mathrm{mg} \mathrm{kg}^{-1}\right)$ & $123 \pm 14$ & $122 \pm 16$ & $0.80 \pm 0.08$ & $0.79 \pm 0.11$ \\
$\mathrm{Cu}\left(\mathrm{mg} \mathrm{kg}^{-1}\right)$ & $18.5 \pm 2.7$ & $18.3 \pm 0.7$ & $9.60 \pm 0.16$ & $9.57 \pm 0.33$ \\
$\mathrm{Fe}(\%)$ & $3.29 \pm 0.1$ & $3.33 \pm 0.03$ & - & - \\
$\mathrm{Hg}\left(\mathrm{mg} \mathrm{kg}^{-1}\right)$ & - & $0.13 \pm 0.04$ & $0.188 \pm 0.007$ & $0.179 \pm 0.019$ \\
$\mathrm{Mn}\left(\mathrm{mg} \mathrm{kg}^{-1}\right)$ & $229 \pm 15$ & $214 \pm 2$ & $7.3 \pm 0.2$ & $6.9 \pm 0.1$ \\
$\mathrm{~Pb}\left(\mathrm{mg} \mathrm{kg}^{-1}\right)$ & $22.7 \pm 3.4$ & $23.6 \pm 0.6$ & $1.91 \pm 0.04$ & $1.91 \pm 0.15$ \\
$\mathrm{Zn}\left(\mathrm{mg} \mathrm{kg}^{-1}\right)$ & $119 \pm 12$ & $110 \pm 2$ & $76 \pm 2$ & $75 \pm 2$ \\
\hline
\end{tabular}

\section{RESULTS AND DISCUSSION}

\subsection{Seawater analyses}

Higher concentrations of nutrients were measured at the high risk station during summer except of nitrate and silicate, whereas no specific trend was detected during autumn (Table 2).

Table 2. Range of nutrient (in $\mu \mathrm{mol} \mathrm{I}^{-1}$ ) and chlorophyll-a concentrations (in $\mu \mathrm{g} \mathrm{I}^{-1}$ ) in seawater samples from the eastern coast of Lesvos during summer and autumn 2004

\begin{tabular}{|ccccccc|}
\hline Station & Phosphate & Ammonia & Nitrite & Nitrate & Silicate & Chl-a \\
\hline \multicolumn{7}{c}{ A. Summer 2004 } \\
GRE51 & $<0.03-0.52$ & $<0.10-0.85$ & $<0.01-0.08$ & $0.12-0.16$ & $0.71-3.65$ & $1.12-1.28$ \\
GRE52 & $<0.03$ & $0.20-0.59$ & $0.02-0.03$ & $0.65-1.76$ & $1.52-14.28$ & $0.03-0.10$ \\
GRE53 & $<0.03$ & $<0.10-0.22$ & $<0.01$ & $0.54-1.28$ & $1.01-4.69$ & $0.02-0.11$ \\
GRE54 & $<0.03-1.00$ & $<0.10$ & $<0.01$ & $0.29-1.04$ & $0.96-2.12$ & $0.03-0.04$ \\
\hline \multicolumn{7}{c}{ B. Autumn 2004 } \\
GRE51 & $0.16-0.26$ & $0.17-0.37$ & $<0.01-0.02$ & - & $3.76-5.47$ & $0.67-1.73$ \\
GRE52 & $0.15-0.34$ & $0.16-0.26$ & $<0.01$ & - & $2.40-9.35$ & $0.03-0.19$ \\
GRE53 & $0.18-0.23$ & $0.15-0.27$ & $<0.01-0.02$ & - & $5.09-9.53$ & $0.02-0.14$ \\
GRE54 & $0.19-0.27$ & $0.19-0.27$ & $<0.01$ & - & $5.31-12.47$ & $0.05-0.12$ \\
\hline
\end{tabular}

* <value: below the limit of detection (value = limit of detection)

Nitrate and phosphate concentrations in the eastern coastal area of Lesvos were high compared to already reported values for Greek coastal waters (Pavlidou et al., 2005), whereas the concentrations of ammonia, nitrite and silicate were relatively low.

Higher concentrations of chlorophyll-a were measured at the high risk station (GRE51) in the vicinity of Mytilini harbour during both summer and autumn 2004, whereas no considerable differences were observed for the reference stations (Table 2). According to available data for Greek coastal areas (Gotsis-Skretas and Ignatiades, 2005) and an existing eutrophication scale proposed by Karydis (2001), the waters along the eastern coast of Lesvos can be 
characterised as oligotrophic or lower mesotrophic, except of Station GRE51 near the harbour of Mytilini which is higher mesotrophic with eutrophic trends.

Polyaromatic hydrocarbons were not detected in seawater samples from the port of Mytilini, with the exception of Fluoranthene in summer, at a concentration of $0.016 \mu \mathrm{g} \mathrm{I}^{-1}$ and Benzo-apyrene in autumn, at a concentration of $0.10 \mu \mathrm{g} \mathrm{I}^{-1}$.

\subsection{Sediments}

\subsubsection{Geochemical parameters}

The granulometric composition and the \% content in organic carbon, calcium carbonate and Fe of sediments from the eastern coast of Lesvos, in 2004 are shown in Table 3. Sediments from reference stations (GRE52-GRE54) are generally sandy, whereas the 'hot spot' station GRE51 near the harbour of Mytilini has a fine-grained textural structure. The only high proportion of coarser fraction (gravel) was found at station GRE52 at cape Agrilios (south end of the eastern coast). Macroscopic examination of the sediment showed that this fraction consists largely of shell fragments, an observation that justifies the high content of carbonate also found in the same sediment. Carbonate comprises about $30 \%$ of the sediment in all the other stations, a value that is in agreement with the findings of previous extensive surveys of sediments in the wider area of the eastern coast of Lesvos. Similar carbonate content was found in sediments from other coastal areas in Greece (Voutsinou-Taliadouri, 1984; Angelidis and Grimanis, 1989).

Table 3. Granulometric composition and content in organic carbon, calcium carbonate and Fe of sediments from the eastern coast of Lesvos, in 2004

\begin{tabular}{|c|c|c|c|c|c|c|}
\hline \multirow[b]{2}{*}{ Station } & \multicolumn{3}{|c|}{ Granulometric composition } & \multirow{2}{*}{$\begin{array}{c}\text { Organic } \\
\text { carbon } \\
(\%)\end{array}$} & \multirow{2}{*}{$\begin{array}{c}\text { Calcium } \\
\text { carbonate } \\
(\%)\end{array}$} & \multirow{2}{*}{$\begin{array}{l}\mathrm{Fe} \\
(\%)\end{array}$} \\
\hline & Silt + Clay (\%) & $\begin{array}{c}\text { Sand } \\
(\%)\end{array}$ & $\begin{array}{c}\text { Gravel } \\
(\%)\end{array}$ & & & \\
\hline GRE51 & 78.1 & 20.1 & 1.8 & 2.28 & 29.2 & 2.14 \\
\hline GRE52 & 22.6 & 48.9 & 28.5 & 0.54 & 50.2 & 1.42 \\
\hline GRE53 & 43.2 & 48.2 & 8.6 & 1.62 & 28.2 & 1.84 \\
\hline GRE54 & 33.9 & 59.5 & 6.6 & 0.82 & 34.1 & 2.15 \\
\hline
\end{tabular}

The highest percentage in organic carbon content was measured near the harbour of Mytilini, where untreated sewerage was discharged for decades. A sewage treatment plant was constructed and started to operate in 2001, so today most of the sewerage of the city of Mytilini is treated. However, a small quantity of untreated sewage is still flowing out in the harbour in the vicinity of station GRE51. The organic carbon contents measured at the reference stations (GRE52-GRE54) were generally typical of coastal sediments (Horowitz, 1991). Iron concentrations were around 2\%, except of station GRE52 where a lower value $(1.42 \%)$ was measured. This lower concentration may be related to the high carbonate content of the sediment at this station. Calcium carbonate, according to the literature, is a substrate geochemically depleted in metals acting as a 'diluant' of metal concentrations in sediments (Horowitz, 1991).

\subsubsection{Metals, polyaromatic and halogenated hydrocarbons}

Metal, polyaromatic and halogenated hydrocarbons concentrations measured in sediment samples from the 'hot spot' station and the reference stations along the eastern coast of Lesvos in 2004 are shown in Table 4. 
Table 4. Concentrations of metals (in $\mathrm{mg} \mathrm{kg}^{-1}$, d.w.), polyaromatic and halogenated hydrocarbons (in $\mathrm{g} \mathrm{kg}^{-1}, \mathrm{~d}$. w.) in sediments from the eastern coast of Lesvos during 2004

\begin{tabular}{|c|c|c|c|c|}
\hline & \multicolumn{4}{|c|}{ Station } \\
\hline & GRE51 & GRE52 & GRE53 & GRE54 \\
\hline $\mathrm{Cd}$ & 0.285 & 0.047 & 0.078 & 0.073 \\
\hline $\mathrm{Cr}$ & 164 & 113 & 117 & 157 \\
\hline $\mathrm{Cu}$ & 39.3 & 7.4 & 16 & 10.3 \\
\hline $\mathrm{Hg}$ & 0.11 & 0.056 & 0.033 & 0.03 \\
\hline $\mathrm{Mn}$ & 259 & 365 & 232 & 322 \\
\hline $\mathrm{Pb}$ & 42.9 & 20.5 & 35.8 & 24.2 \\
\hline $\mathrm{Zn}$ & 113 & 38 & 58 & 46 \\
\hline Anthracene & 26.1 & 0.8 & 0.8 & 0.4 \\
\hline Fluoranthene & 24 & 1.4 & 3.3 & 0.4 \\
\hline Benzo-b-fluoranthene & 82.7 & 4.7 & 14.3 & $<0.25^{*}$ \\
\hline Benzo-k-fluoranthene & 22.3 & 0.8 & 3.2 & $<0.5$ \\
\hline Benzo-a-pyrene & 57.6 & 3.7 & 13.2 & $<0.25$ \\
\hline Indeno-123cd-pyrene & 37.3 & 3 & 9.9 & $<0.5$ \\
\hline Total $\mathrm{PAH}^{* *}$ & 250 & 14.4 & 44.7 & 1.6 \\
\hline$p, p^{\prime}-D D E$ & $<0.5$ & $<0.5$ & $<0.5$ & $<0.5$ \\
\hline$p, p^{\prime}-D D D$ & $<0.6$ & $<0.6$ & $<0.6$ & $<0.6$ \\
\hline p,p'-DDT & $<0.5$ & $<0.5$ & $<0.5$ & $<0.5$ \\
\hline Aldrin & $<0.3$ & $<0.3$ & $<0.3$ & $<0.3$ \\
\hline Dieldrin & $<0.4$ & $<0.4$ & $<0.4$ & $<0.4$ \\
\hline Endrin & $<1.0$ & $<1.0$ & $<1.0$ & $<1.0$ \\
\hline a-hexachlorocyclohexane & $<0.5$ & $<0.5$ & $<0.5$ & $<0.5$ \\
\hline b-hexachlorocyclohexane & $<0.5$ & $<0.5$ & $<0.5$ & $<0.5$ \\
\hline d-hexachlorocyclohexane & $<0.8$ & $<0.8$ & $<0.8$ & $<0.8$ \\
\hline Lindane & $<0.5$ & $<0.5$ & $<0.5$ & $<0.5$ \\
\hline hexachlorocyclobenzene & $<0.2$ & $<0.2$ & $<0.2$ & $<0.2$ \\
\hline heptachlor epoxide & $<0.4$ & $<0.4$ & $<0.4$ & $<0.4$ \\
\hline
\end{tabular}

* <value: below the limit of detection (value = limit of detection)

** for the calculation of total PAHs, half of the limit of detection was used as an estimate of concentration of non-detected compounds

Metal concentrations are lower compared to values from polluted areas in other parts of Greece. In general, metal levels are similar to concentrations reported for other areas in the eastern and central Aegean Sea and in closed sea-water bodies in Greece with no significant metal contamination (see Table 5 for comparison). 
Table 5: Metal concentrations in sediments from contaminated and non-contaminated areas in Greece

\begin{tabular}{|c|c|c|c|c|c|c|c|c|}
\hline $\begin{array}{l}\text { Study area, method, } \\
\text { sediment granulometric } \\
\text { fraction }\end{array}$ & $\begin{array}{c}\mathrm{Cd} \\
\left(\mathrm{mg} \mathrm{kg}^{-1}\right)\end{array}$ & $\begin{array}{c}\mathrm{Cr} \\
\left(\mathrm{mg} \mathrm{kg}^{-1}\right)\end{array}$ & $\begin{array}{c}\mathrm{Cu} \\
\left(\mathrm{mg} \mathrm{kg}^{-1}\right)\end{array}$ & $\begin{array}{l}\mathrm{Fe} \\
(\%)\end{array}$ & $\begin{array}{c}\mathrm{Mn} \\
\left(\mathrm{mg} \mathrm{kg}^{-1}\right)\end{array}$ & $\begin{array}{c}\mathrm{Pb} \\
\left(\mathrm{mg} \mathrm{kg}^{-1}\right)\end{array}$ & $\begin{array}{c}\mathrm{Zn} \\
\left(\mathrm{mg} \mathrm{kg}^{-1}\right)\end{array}$ & Source \\
\hline $\begin{array}{l}\text { Eastern coast of Lesvos, } \\
\text { total, }<2 \mathrm{~mm}\end{array}$ & $0.05-0.29$ & $113-164$ & $7.4-39.3$ & $1.42-2.15$ & $232-365$ & $20.5-42.9$ & $38-113$ & This study \\
\hline $\begin{array}{l}\text { Eastern coast of Lesvos, } \\
\text { total, }<1 \mathrm{~mm}\end{array}$ & $0.03-0.23$ & $40-138$ & $5.34-48.8$ & $0.77-2.75$ & $171-360$ & $20.7-63.3$ & $13-134$ & $\begin{array}{l}\text { Aloupi and Angelidis, } \\
2001\end{array}$ \\
\hline $\begin{array}{l}\text { Port of Mytilini, total, } \\
<1 \mathrm{~mm}\end{array}$ & $0.17-0.50$ & $108-154$ & $43.1-86.2$ & $2.19-2.81$ & $242-266$ & $52-93$ & $112-230$ & $\begin{array}{l}\text { Aloupi and Angelidis, } \\
2001\end{array}$ \\
\hline $\begin{array}{l}\text { Port of Piraeus, total, } \\
<2 \mu \mathrm{m}\end{array}$ & $0.6-54.7$ & $46-2740$ & $144-3618$ & $3.7-153.6$ & $54-878$ & $193-2094$ & $130-4420$ & Boboti et al., 1985 \\
\hline Elefsis Gulf, total & - & - & $25-150$ & - & $350-1000$ & $160-500$ & $125-1500$ & Scoullos, 1979 \\
\hline $\begin{array}{l}\text { Saronicos Gulf, total } \\
<55 \mu \mathrm{m}\end{array}$ & - & $180-680$ & - & 9.476 .0 & - & - & $100-1500$ & $\begin{array}{c}\text { Angelidis and Grimanis, } \\
1989\end{array}$ \\
\hline $\begin{array}{l}\text { Thermaikos Gulf - } \\
\text { contaminated, c. } \mathrm{HNO}_{3} \text {, } \\
<2 \mathrm{~mm}\end{array}$ & $0.45-1.15$ & $80-280$ & $45-70$ & $35-55$ & - & $45-310$ & $110-600$ & $\begin{array}{c}\text { Voutsinou-Taliadouri, } \\
1982\end{array}$ \\
\hline $\begin{array}{l}\text { Thermaikos Gulf }- \text { non } \\
\text { contaminated, c. } \mathrm{HNO}_{3} \text {, } \\
<2 \mathrm{~mm}\end{array}$ & $<0.40$ & $40-165$ & $5-20$ & $15-25$ & - & $15-45$ & $30-195$ & $\begin{array}{l}\text { Voutsinou-Taliadouri, } \\
1982\end{array}$ \\
\hline $\begin{array}{l}\text { Gulf of Kavala, } 2 \mathrm{~N} \mathrm{HCl} \text {, } \\
<2 \mathrm{~mm}\end{array}$ & - & $20-278$ & $4-227$ & $7.4-26.5$ & $65-417$ & $5-908$ & $24-510$ & $\begin{array}{c}\text { Voutsinou-Taliadouri, } \\
1982\end{array}$ \\
\hline $\begin{array}{l}\text { Gulf of Volos, c. } \mathrm{HNO}_{3}, \\
<2 \mathrm{~mm}\end{array}$ & $<0.40$ & $35-220$ & $15-50$ & $15-65$ & $255-2010$ & $20-50$ & $30-945$ & $\begin{array}{c}\text { Voutsinou-Taliadouri, } \\
1982\end{array}$ \\
\hline
\end{tabular}


Table 5: Metal concentrations in sediments from contaminated and non-contaminated areas in Greece (continued)

\begin{tabular}{|c|c|c|c|c|c|c|c|c|}
\hline $\begin{array}{l}\text { Study area, method, } \\
\text { sediment granulometric } \\
\text { fraction }\end{array}$ & $\begin{array}{c}\mathrm{Cd} \\
\left(\mathrm{mg} \mathrm{kg}^{-1}\right)\end{array}$ & $\begin{array}{c}\mathrm{Cr} \\
\left(\mathrm{mg} \mathrm{kg}^{-1}\right)\end{array}$ & $\begin{array}{c}\mathrm{Cu} \\
\left(\mathrm{mg} \mathrm{kg}^{-1}\right)\end{array}$ & $\begin{array}{l}\mathrm{Fe} \\
(\%)\end{array}$ & $\begin{array}{c}\mathrm{Mn} \\
\left(\mathrm{mg} \mathrm{kg}^{-1}\right)\end{array}$ & $\begin{array}{c}\mathrm{Pb} \\
\left(\mathrm{mg} \mathrm{kg}^{-1}\right)\end{array}$ & $\begin{array}{c}\mathrm{Zn} \\
\left(\mathrm{mg} \mathrm{kg}^{-1}\right)\end{array}$ & Source \\
\hline $\begin{array}{l}\text { Pagassitikos Gulf, } 2 \mathrm{~N} \\
\mathrm{HCl},<2 \mathrm{~mm}\end{array}$ & $<0.40$ & $67-222$ & $13-27$ & $8.0-29.2$ & $213-3050$ & $19-28$ & $44-72$ & $\begin{array}{c}\text { Voutsinou-Taliadouri } \\
\text { and Georgakopoulou- } \\
\text { Grigoriadou, } 1989\end{array}$ \\
\hline $\begin{array}{l}\text { Patraikos Gulf, total } \\
<63 \mu \mathrm{m}\end{array}$ & - & $70-210$ & 23-101 & - & - & $10-40$ & $275-430$ & $\begin{array}{l}\text { Varnavas and } \\
\text { Ferentinos, } 1982\end{array}$ \\
\hline $\begin{array}{l}\text { Amvrakikos Gulf, } 2 \mathrm{~N} \mathrm{HCl} \text {, } \\
<2 \mathrm{~mm}\end{array}$ & & $27-177$ & $2-45$ & $4.9-30.5$ & $323-3820$ & $7-21$ & $12-85$ & $\begin{array}{c}\text { Voutsinou-Taliadouri, } \\
1989\end{array}$ \\
\hline Gulf of Kalamata, total & - & -418 & $11-56$ & -60.9 & -3600 & $8-40$ & -355 & Varnavas et al., 1984 \\
\hline $\begin{array}{l}\text { Gulf of Navarino, } 2 \mathrm{~N} \mathrm{HCl} \text {, } \\
<2 \mathrm{~mm}\end{array}$ & - & $12-251$ & $0-32$ & $2.0-30.0$ & $243-600$ & $2-53$ & $7-81$ & $\begin{array}{c}\text { Voutsinou-Taliadouri, } \\
1989\end{array}$ \\
\hline Gulf of Navarino, total & $0.04-3.0$ & - & $30-66$ & - & - & $9-59$ & - & Varnavas et al., 1985 \\
\hline $\begin{array}{l}\text { Straight of Evripos, total, } \\
<61 \mu \mathrm{m}\end{array}$ & - & - & $28.4-80.4$ & - & $351-676$ & $27.5-110$ & $77-377$ & Dassenakis et al.,1996 \\
\hline $\begin{array}{l}\text { S. Evoikos Gulf, total } \\
<55 \mu \mathrm{m}\end{array}$ & - & - & - & $23.6-41.9$ & - & - & $52.6-147$ & Angelidis et al.,1980 \\
\hline $\begin{array}{l}\text { N. Evoikos Gulf, } 2 \mathrm{~N} \mathrm{HCl} \text {, } \\
<2 \mathrm{~mm}\end{array}$ & - & $40-41000$ & $0-28$ & - & - & $0-27$ & $9-58$ & $\begin{array}{l}\text { Voutsinou-Taliadouri } \\
\text { and Varnavas, } 1985\end{array}$ \\
\hline $\begin{array}{l}\text { Eastern Aegean, c. } \mathrm{HNO}_{3} \text {, } \\
<2 \mathrm{~mm}\end{array}$ & $0.106-0.186$ & $19-166$ & $5.6-30.3$ & $13.5-37.3$ & $270-2920$ & $10.0-22.9$ & $24.0-56.5$ & $\begin{array}{l}\text { Voutsinou-Taliadouri } \\
\text { and Satsmadjis, } 1982\end{array}$ \\
\hline $\begin{array}{l}\text { S. Evoikos Gulf, total, } \\
<1 \mathrm{~mm}\end{array}$ & $0.09-0.65$ & $246-404$ & $11-43$ & $19.3-52.3$ & $330-552$ & $7.28-36.7$ & $40-129$ & $\begin{array}{l}\text { Angelidis and Aloupi, } \\
2000\end{array}$ \\
\hline
\end{tabular}


The highest concentrations of all metals except Mn were measured at station GRE51, near the harbour of Mytilini. Higher levels of metals at this station are to be expected on the grounds of the almost double silt and clay content of the sediment at this station, compared to the other stations. This fine-grained fraction is the main carrier of metals in sediments Horowitz, 1991).

In order to assess whether the observed high metal concentrations represent contamination of sediments, investigation of the relationships among concentrations of different metals and Fe (normalisation) was performed (Loring, 1991). This statistical procedure aims at the expression of the data on a uniform basis, after mathematically eliminating specific factors that is well known to cause variability, such as grain size distribution, carbonate content, organic carbon content, or mineralogy, the latter by the means of a conservative element. Geochemical normalization to a conservative element has the advantage of compensating simultaneously both for grain size and mineralogical variability. The technique consists of establishing the relationships between metal concentrations and the concentrations of a conservative element, by estimating the relative linear regression model along with the $95 \%$ or $99 \%$ confidence band (Aloupi and Angelidis, 2001a). Elements of natural origin which are structurally combined with one or more of the major fine-grained trace metal carriers are considered as representing a certain mineral fraction of the sediment and are characterised as conservative. Several conservative elements have been used for normalization purposes, Fe being one of them (Piper, 1971; Rule, 1986; Blomqvist et al., 1992; Herut et al.,1993; Daskalakis and O'Connor, 1995).
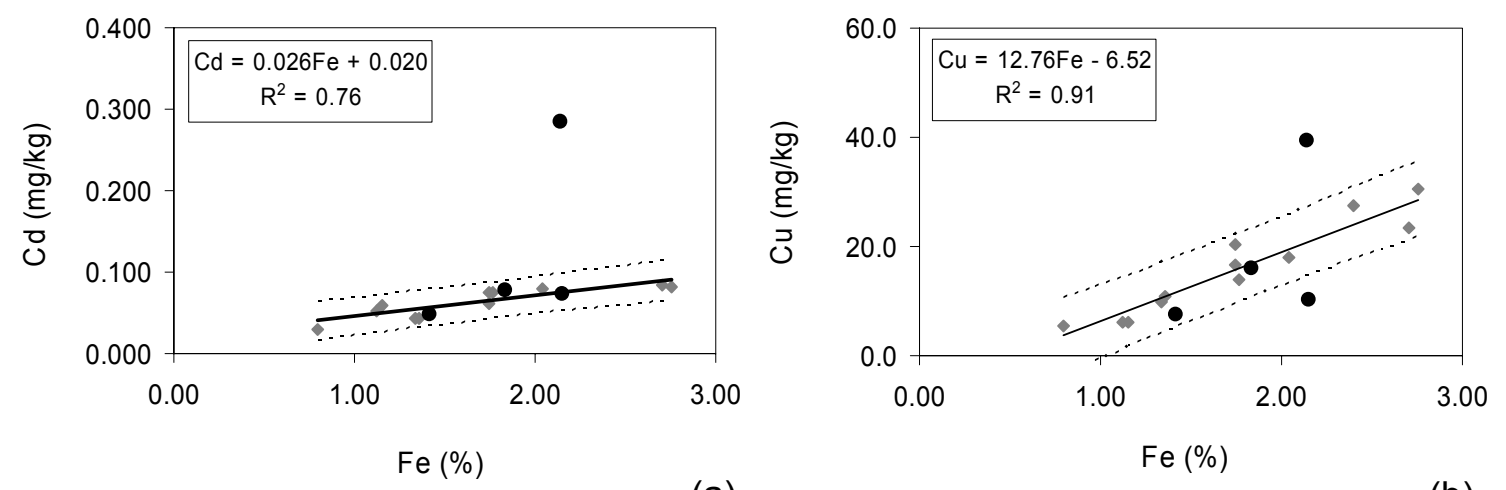

(a)

(b)

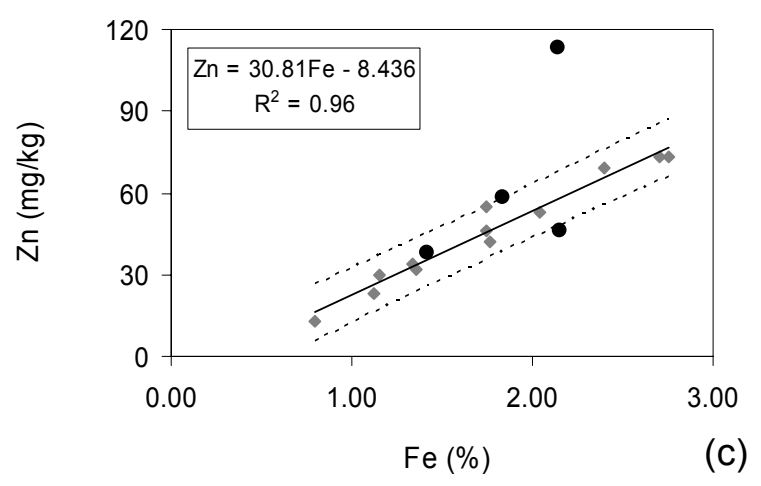

Figure 2. Cd:Fe (a), Cu: Fe (b) and Zn:Fe (c) normalisation plots for sediments of the Eastern coast of Lesvos. Points in grey represent previous data used for the production of regression model, points in black represent data of this survey

In the present study, the linear regression models used for the normalisation of metal concentrations to Fe were developed using data for the study area from previous surveys (Aloupi and Angelidis, 2001a). Then, present data were projected on the regression plots. All points within the $95 \%$ confidence band of the model were considered as representing natural sediments, whereas points above this area were characterized as representing contaminated sediments (Loring,1990; Loring and Rantala, 1992). Normalisation of $\mathrm{Hg}$ values was not feasible, because of lack of previous data for the metal. 
Normalisation to Fe revealed a pronounced contamination of the sediment at station GRE51 in $\mathrm{Cd}, \mathrm{Cu}, \mathrm{Zn}$ (Figure 2). All these are metals mainly originating from human-related sources. The contamination of the sediment at station GRE51 with anthropogenic metals, also recorded in previous surveys, may be attributed to the long-lasting discharge of untreated domestic effluents to the adjacent sea (Aloupi et al., 2000). The present survey shows that although the uncontrolled discharge of effluents has been reduced since the beginning of the operation of the treatment plant some years ago, sediments still carry increased loads of anthopogenic metals, although not at such a high level to consider the area as seriously polluted.

On the other hand, no anthropogenic influence was detected for $\mathrm{Cr}$ and $\mathrm{Pb}$ in the studied samples (Figure 3), although both metals are also associated with human activities. In the case of $\mathrm{Cr}$, this finding is in accordance with previous studies (Aloupi and Angelidis, 2001a), where only a minor contamination was observed in the sediment of the restricted area of the harbour of Mytilini. On the contrary, $\mathrm{Pb}$ was found in noticeably enhanced concentrations in the past, in both surface and deeper sediments of Mytilini's harbour (Aloupi and Angelidis, $2001 a, b)$. This contamination had been attributed to the extended use of leaded gasoline by vehicles in previous years, because of the lack of other sources of lead in the area. Therefore, the reduction of the $\mathrm{Pb}$ pollution levels may be associated with the restriction in the use of leaded gasoline for transportation, an assumption that needs to be confirmed in future studies.
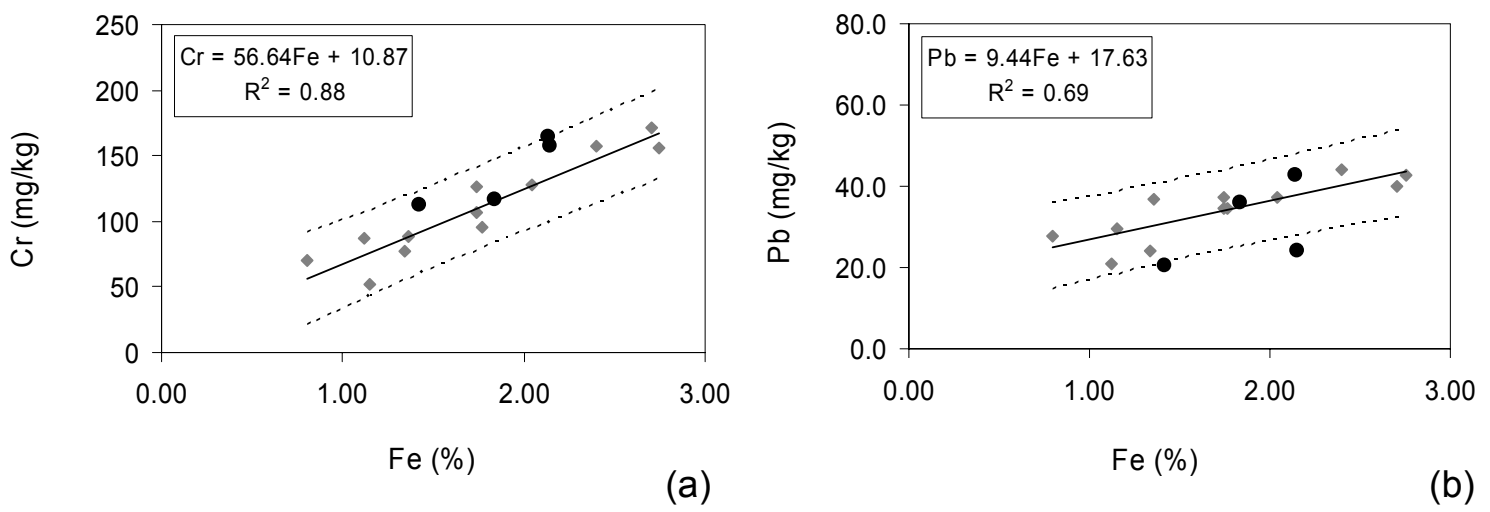

Figure 3. $\mathrm{Cr}: \mathrm{Fe}(\mathrm{a})$ and $\mathrm{Pb}: \mathrm{Fe}(\mathrm{b})$ normalisation plots for sediments of the eastern coast of Lesvos. Points in grey represent previous data used for the production of regression model, points in black represent data of this survey

The concentrations of the polyaromatic hydrocarbons measured in the present survey are low compared to values already found in heavily contaminated areas as Elefsis Bay (Sklivagou et al., 2001) and French Riviera (Baumard et al., 1998). The highest concentrations of the polyaromatic hydrocarbons measured in the present survey were found in the sediment near the harbour of Mytilini. A trend of decreasing values was observed in the reference stations, in the order GRE53>GRE52>GRE54. It seems that the relatively higher contamination of sediments with polyaromatic hydrocarbons is low near Mytilini, gradually decreasing southwards, whereas no contamination was found at the Thermi bay (Station GRE54), in to the north of Mytilini. Among the determined PAHs, Benzo-b-fluoranthene showed the highest concentrations at all stations, followed by Benzo-a-pyrene. Finally, the concentrations of the halogenated hydrocarbons determined in the sediments from the eastern coast of Lesvos were all found below the detection limit.

\subsection{Biota}

Metal concentrations in the fish flesh (Table 6 ) are similar in both species, with the exception of $\mathrm{Hg}$. Mercury concentration is higher in the benthic species $M$. barbatus than in the pelagic species B. boops. Kücüksezgin et al. (2001) in a study on trace metal and organochlorine residue levels in red mullet (Mullus barbatus) along the Aegean coast of Turkey mention that $\mathrm{Hg}$ concentrations in fish originate from food. In addition, Storelli et al. (2005) in a similar survey in the Adriatic Sea suggest that different metal loads in different fish species dwelling 
in the same area show that either abiotic factors, such as seawater and sediment, or biotic factors, including trophic level or size, determine the uptake and accumulation of $\mathrm{Hg}$. It was concluded in the same study, that benthic species have higher $\mathrm{Hg}$ concentrations in their flesh than pelagic, assigning this finding to the importance of the sediment in the metal's biogeochemical cycle. This latter conclusion is also confirmed in the present study.

Table 6. Concentrations of metals (in $\mathrm{mg} \mathrm{kg}^{-1}$, d.w.), polyaromatic and halogenated hydrocarbons (in $\mu \mathrm{g} \mathrm{kg}^{-1} \mathrm{~d} . \mathrm{w}$.), in the flesh of fish collected in the eastern coast of Lesvos during 2004

\begin{tabular}{|c|c|c|}
\hline & $\begin{array}{c}\text { M. barbatus } \\
\text { Pooled sample } \\
n=10\end{array}$ & $\begin{array}{c}\text { B. boops } \\
\text { Pooled sample } \\
n=10\end{array}$ \\
\hline $\mathrm{Cd}$ & 0.007 & 0.007 \\
\hline $\mathrm{Cr}$ & 0.18 & 0.15 \\
\hline $\mathrm{Cu}$ & 1.54 & 1.13 \\
\hline $\mathrm{Hg}$ & 0.354 & 0.147 \\
\hline $\mathrm{Mn}$ & 0.75 & 0.67 \\
\hline $\mathrm{Pb}$ & 0.046 & 0.061 \\
\hline $\mathrm{Zn}$ & 22 & 27 \\
\hline Anthracene & $<0.05$ & $<0.05$ \\
\hline Fluoranthene & $<0.025$ & $<0.025$ \\
\hline Benzo-b-fluoranthene & $<0.25$ & $<0.25$ \\
\hline Benzo-k-fluoranthene & $<0.5$ & $<0.5$ \\
\hline Benzo-a-pyrene & $<0.25$ & $<0.25$ \\
\hline Indeno-123cd-pyrene & $<0.5$ & $<0.5$ \\
\hline p,p'-DDE & $<0.5$ & $<0.5$ \\
\hline p,p'-DDD & $<0.6$ & $<0.6$ \\
\hline p,p'-DDT & $<0.5$ & $<0.5$ \\
\hline Aldrin & $<0.3$ & $<0.3$ \\
\hline Dieldrin & $<0.4$ & $<0.4$ \\
\hline Endrin & $<1.0$ & $<1.0$ \\
\hline a-hexachlorocyclohexane & $<0.5$ & $<0.5$ \\
\hline b-hexachlorocyclohexane & $<0.5$ & $<0.5$ \\
\hline d-hexachlorocyclohexane & $<0.8$ & $<0.8$ \\
\hline Lindane & $<0.5$ & $<0.5$ \\
\hline Hexachlorocyclobenzene & $<0.2$ & $<0.2$ \\
\hline heptachlor epoxide & $<0.4$ & $<0.4$ \\
\hline
\end{tabular}

* < value: below the limit of detection (value = limit of detection)

Metal concentrations in fish flesh measured in the present study, expressed in $\mathrm{mg} / \mathrm{kg}$ of dry weight, are presented in Figure 5 along with literature values (Küçüksezgin et al., 2001; Storelli et al., 2005; Catsiki and Strogyloudi,1999a; Catsiki and Strogyloudi,1999b; Storelli and Marcotrigiano, 2005; Türkmen et al., 2005; Kalay et al., 1999; Zyadah and Chouikhi, 1999; Yazkan et al., 2002; Kljaković Gaspic et al., 2002; Küçüksezgin and Balci, 1994; Celik and Oehlenschlasäger, 2005). Concentrations expressed in wet weight were previously converted to dry weight for comparison, by assuming an average water content of $80 \%$, determined in 
the present study. The metal concentrations measured in both fish species in the present study have shown great variability, however they were very low compared to already reported values from other coastal areas in Greece or in the Mediterranean.

Polyaromatic and halogenated hydrocarbons were not detected in both pooled fish flesh samples.

Cd

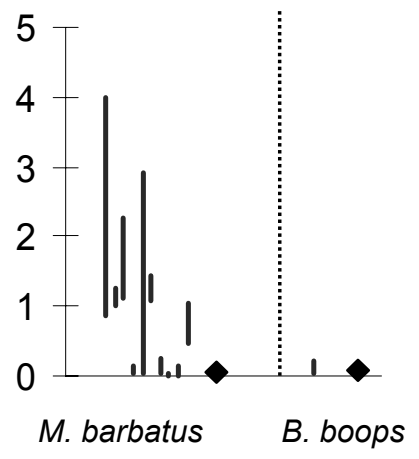

$\mathrm{Cr}$

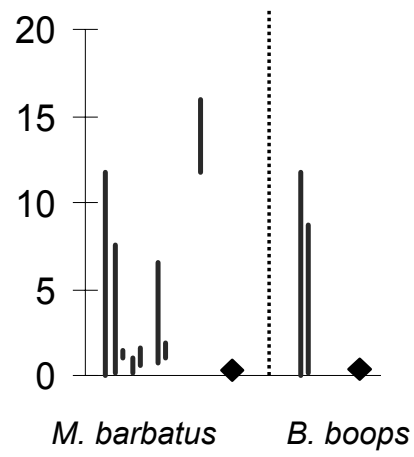

$\mathrm{Cu}$

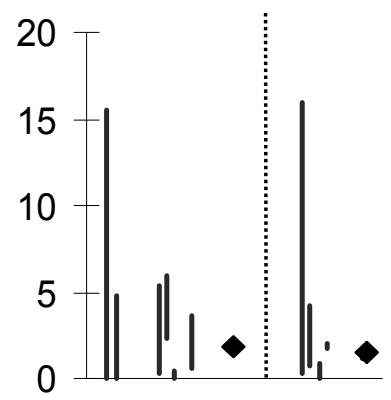

$\begin{array}{ll}\text { M. barbatus } \quad \text { B. boops } & \end{array}$
Mn

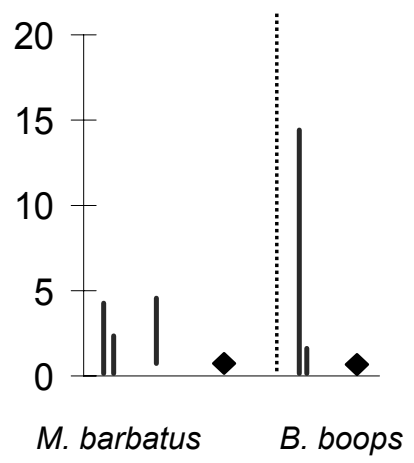

$\mathrm{Pb}$

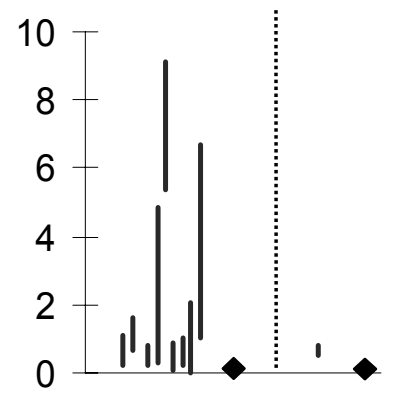

M. barbatus

B. boops

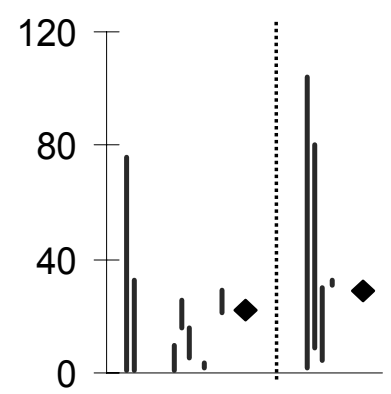

$\begin{array}{ll}\text { M. barbatus } \quad \text { B. boops } & \end{array}$

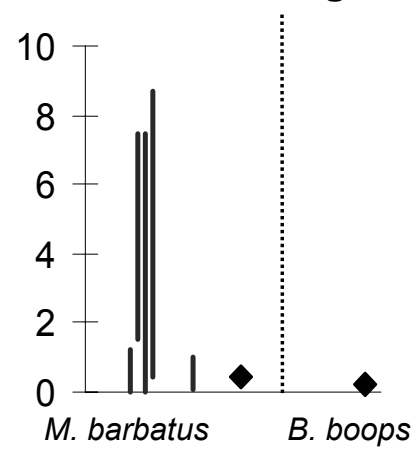

Figure 5. Metal concentrations in $\mathrm{mg} \mathrm{kg}^{-1}$ (dry weight) in $M$. barbatus and B. boops found in samples from the eastern coast of Lesvos (diamonds) and reported in the literature (bars) 


\section{CONCLUSIONS}

According to the recent information collected along the eastern coastal area of Lesvos in the framework of the monitoring programme MEDPOL III, it seems that there is no evidence of substantial pollution of the marine environment (seawater, sediment and fish) with respect to the pollutants measured. However, it was shown that although the uncontrolled discharge of untreated effluents has been reduced since the beginning of the operation of the treatment plant in 2001, sediments near the harbour of Mytilini still carry increased loads of anthropogenic metals, though not at such a high level to consider the area as seriously polluted. The small quantity of untreated sewerage that still flows out in the harbour also seems to affect water quality, since a higher mesotrophic character with eutrophic trends was observed in the area.

\section{REFERENCES}

1. Aloupi M. and Angelidis M.O. (2001a) Geochemistry of natural and anthropogenic metals in the coastal sediments of the island of Lesvos, Aegean Sea, Environmental Pollution, 113(2), 211-219.

2. Aloupi M. and Angelidis M.O. (2001b) Normalization to lithium for the assessment of metal contamination in coastal sediment cores from the Aegean Sea, Greece, Marine Environmental Research, 52(1), 1-12.

3. Aloupi M., Scoullos M. and Angelidis M.O. (2000) Spatial and temporal variability of composition of urban effluents in the island of Lesvos, Greece, Environment International, 26, 29-35.

4. Angelidis M. and Grimanis A.P. (1989) Geochemical partitioning of Co, Cr, Fe, Sc and Zn, in polluted and non-polluted marine sediments, Environ. Pollut., 62, 31-46.

5. Angelidis M., Grimanis A.P., Zafiropoulos D. and Vassilaki-Grimani M. (1980) Trace elements in sediments of Evoikos gulf, Greece, Vles J. Etud. Pollut., Cagliari, C.I.E.S.M., 5, 413-418.

6. Angelidis M.O., Aloupi M. (2000) Geochemical study of coastal sediments influenced by rivertransported pollution: Southern Evoikos Gulf, Greece, Marine Pollution Bulletin, 40(1), 77-82.

7. Arhonditsis G., Eleftheriadou M., Karydis M. and Tsirtsis G. (2003) Eutrophication risk assessment in coastal embayments using simple statistical models, Marine Pollution Bulletin, 46(9), 1174-1178.

8. Baumard P., Budzinski H., Garrigues P. (1998) Polycyclic Aromatic Hydrocarbons in Sediments and Mussels of the Western Mediterranean Sea, Environmental Toxicology and Chemistry, 17(5), 765-776.

9. Blomqvist S., Larsson U. and Borg H. (1992) Heavy metal decrease in the sediments of a Baltic Bay following tertiary sewage treatment, Marine Pollution Bulletin, 24, 258-266.

10. Boboti A., Stoffers P. and Muller G. (1985) Heavy metal pollution in the harbour area of Piraeus, Greece, Heavy Metals in the Environment, Athens, 2, 407-410.

11. Catsiki V.-A. and Strogyloudi E. (1999a) Comparative use of bioindicators for the study of temporal trends in metal marine pollution $6^{\text {th }}$ International Conference of Environmental Science and Technology, Pythagorio, Samos, Greece, 467-473 (in greek).

12. Catsiki V.-A. and Strogyloudi E. (1999b) Survey of metal levels in common fish species from Greek waters, The Science of the Total Environment, 237-238, 387-400.

13. Celik U. and Oehlenschlasäger J. (2005) Zinc and copper content in marine fish samples collected from the eastern Mediterranean Sea, European Food Research and Technology, 220(1), 37-41.

14. Daskalakis K.D. and O'Connor T.P. (1995) Normalization and elemental sediment contamination in the coastal United States, Environ. Sci. Technol., 29, 470-477.

15. Dassenakis M.I., Kloukiniotou M.A. and Pavlidou A.S. (1996) The influence of long existing pollution on trace metal levels in a small tidal Mediterranean bay, Mar. Pollut. Bull., 32, 275282.

16. FAO/UNEP (1994). Second FAO/UNEP sub-regional workshop on the monitoring of chemical contaminants in marine biota for trends, Lesvos, Greece.

17. Friligos N., Giourga C., Karydis M. and Margaris N.S. (1994) Modern Agricultural Practices and eutrophication in Pagassitikos Gulf, Greece, Ecologia Mediterranea, 20(1/2), 59-65. 
18. Gotsis-Skretas O. and Ignatiades L. (2005) Phytoplankton in pelagic and coastal waters, In: State of the Hellenic Marine Environment, Papathanassiou, E. and Zenetos, A. (Eds.), HCMR Publ., 360 pp.

19. Herut B., Hornung H., Krom M.D., Kress N. and Cohen Y. (1993) Trace metals in shallow sediments from the Mediterranean coastal region of Israel, Marine Pollution Bulletin, 26, 675682.

20. Horowitz A.J., (1991) A Primer on Sediment - Trace Element Chemistry Lewis Publ.

21. Ignatiades L., Psarra S., Zervakis V., Pagou K., Souvermezoglou E., Assimakopoulou G. and Gotsis-Skretas O. (2002) Phytoplankton size-based dynamics in the Aegean Sea (Eastern Mediterranean, J. Mar. Sys., 36, 11-28.

22. Kalay M., Ay O. and Canli M. (1999) Heavy metal concentrations in fish tissues from the Northeast Mediterranean Sea, Bulletin Environmental Contamination and Toxicology, 63, 673681.

23. Karydis M. (1992) Scaling methods in assessing environmental quality: a methodological approach to eutrophication, Environmental Monitoring and Assessment, 22, 123-136.

24. Karydis M. (1994) Environmental Quality Assessment Based on the Analysis of Extreme Values: A Practical Approach for Evaluating Eutrophication, Journal of Environmental Science and Health, A29(4), 775-791.

25. Karydis M. and Tsirtsis G. (1996) Ecological indices: a biometric approach for assessing eutrophication levels in the marine environment, Science of the Total Environment, 186, 209219.

26. Karydis M. (2001) Assessing levels of eutrophication: A short review on quantitative methodology, Biologia Gallo-hellenica, 27, 135-144.

27. Kljaković Gaspic Z., Zvonarić T., Vrgoč N., Odzak N. and Barić A. (2002) Cadmium and lead in selected tissues of two commercially important fish species from the Adriatic Sea, Water Research, 36(20), 5023-5028.

28. Küçüksezgin F. and Balci A. (1994). Heavy metal concentrations in selected organisms from Izmir Bay, Turkey, Marine Pollution Bulletin, 28(5), 333-335.

29. Küçüksezgin F., Altay O., Uluturhan E. and Kontas A. (2001) Trace metal and organochlorine residue levels in red mullet (Mullus barbatus) from the Eastern Aegean, Turkey, Water Research, 35(9), 2327-2332.

30. Liddicoat M.T., Tibbits S. and Butler E.T. (1974) The detrmination of ammonia in seawater, Limnol. Oceanogr. 20, 131-132.

31. Loring D.H. (1990) Lithium - a new approach for the granulometric normalization of trace metal data, Mar. Chem., 29, 155-168.

32. Loring D.H. (1991) Normalization of heavy-metal data from estuarine and coastal sediments, ICES J. Mar. Sci., 48, 101-115.

33. Loring D.H. and Rantala R.T.T. (1992). Manual for the geochemical analysis of marine sediments and suspended particulate matter, Earth Sci. Reviews, 32, 235-283.

34. Neveux J. and Panouse M. (1987), Spectrofluorometric determination of chlorophylls and phaeophytins Arch. Hydrobiol., 109(4), 567-581.

35. Nikolaou A.D., Kanaki M., Lekkas T.D. (2004) Development of a simple method for the simultaneous determination of nonylphenol, octylphenol, DEHP and PAHs in water samples 4th Aegean Analytical Chemistry Days, 29 September-1 October 2004, Kusadasi, Turkey (poster presentation).

36. Pagou K. and Ignatiades L. (1990) The periodocity of Gymnodinium breve (Davis) in Saronikos Gulf, Aegean Sea, In: Toxic marine phytoplankton, Graneli, E. Sundstorm, B., Edler, L. and Anderson, D.M. (Eds.), Elsevier, New York.

37. Parsons T.R., Maita Y. and Lalli C.M. (1984), A manual of chemical and biological methods for seawater analysis Pergamon Press, New York.

38. Pavlidou A., Psyllidou-Giouranovits R. and Sylaios G.K. (2005) Nutrients and dissolved oxygen in Hellenic coastal waters, in State of the Hellenic Marine Environment, Papathanassiou, E. and Zenetos, A. (Eds.), HCMR Publ., 360 pp.

39. Piper D.Z. (1971) The distribution of $\mathrm{Co}, \mathrm{Cr} \mathrm{Cu}, \mathrm{Fe}, \mathrm{Mn}, \mathrm{Ni}$ and $\mathrm{Zn}$ in Framvaren, a Norwegian anoxic fjord, Geochim. Cosmochim. Acta, 35, 531-559.

40. Rule J.H (1986) Assessment of trace element geochemistry of Hampton Roads Harbor and lower Chesapeake Bay area sediments, Environ. Geol. Water Sci., 8, 209-219. 
41. Scoullos M. (1979) Chemical studies in the Gulf of Elefsis, Greece. PhD Thesis, Dept of Oceanography, The University of Liverpool, U.K.

42. Sklivagou E., Varnavas S.P., Hatzianestis J. (2001) Aliphatic and polycyclic aromatic hydrocarbons in surface sediments from Elefsis Bay, Greece (Eastern Mediterranean), Toxicological and Environmental Chemistry, 79, 195-210.

43. Storelli M.M. and Marcotrigiano G.O. (2005) Bioindicator organisms: Heavy metal pollution evaluation in the Ionian Sea (Mediterranean Sea-Italy), Environmental Monitoring and Assessment, 102, 159-166.

44. Storelli M.M., Storelli A., Giacominelli-Stuffler R. and Marcotrigiano G.O. (2005) Mercury speciation in the muscle of two commercially important fish, hake (Merluccius merluccius) and striped mullet (Mullus barbatus) from the Mediterranean sea: estimated weekly intake, Food Chemistry, 89, 295-300.

45. Tsirtsis G. and Karydis M. (1998a) Evaluation of phytoplankton community indices for detecting eutrophic trends in the marine environment, Environmental Monitoring and Assessment, 50, 255-269.

46. Tsirtsis G. and Karydis M. (1998b) Coastal eutrophication assessment: Development of a water quality classification system using phytoplankton ecological indices, Rapp. Comm. Int. Mer Medit. 35, 590.

47. Tsirtsis G. and Karydis M. (1999) Application of discriminant analysis for water quality assessment in the Aegean, In: Proceedings of the 6th Conference on Environmental Science and Technology, Lekkas, Th. (Ed.), Univ. of the Aegean.

48. Türkmen A., Türkmen M., Tepe Y., Akyurt I. (2005) Heavy metals in three commercially valuable fish species from Iskenderun Bay, Northern East Mediterranean Sea, Turkey, Food Chemistry, 91, 167-172.

49. Varnavas S.P. and Ferentinos G. (1982) Heavy metal distribution in the surface sediments of Patraikos bay, Greece, Vles J. Etud. Pollut., Cannes, C.I.E.S.M., 6, 405-409.

50. Varnavas S.P., Panagos A.G. and Laios G. (1985) Levels, origin and behaviour of mercury, cadmium, silver and molybdenum in surface sediments of Navarino Bay, Greece, Heavy Metals in the Environment, Athens, 2, 415-417.

51. Varnavas S.P., Panagos A.G. and Laios G. (1984) Heavy metal distribution in surface sediments from the Kalamata Bay, Greece, VIles J. Etud. Pollut., Cannes, C.I.E.S.M., 7, 267274.

52. Voutsinou-Taliadouri F. (1982), Metal concentrations in polluted and unpolluted Greek sediments: a comparative study, VI Journ.Etud. Pollut., 245-259.

53. Voutsinou-Taliadouri F. (1984), Syrvey of metal pollution in greek sediments, VII ${ }^{e s} \mathrm{~J}$. Etud. Pollut., Lucerne, C.I.E.S.M., 7, 251-259.

54. Voutsinou-Taliadouri F. and Georgakopoulou-Grigoriadou E. (1989) Heavy metal concentrations in surface sediments from Pagassitikos Gulf, Greece, Toxicol. Environ. Chem., 20-21, 53-58.

55. Voutsinou-Taliadouri F. and Varnavas S.P. (1985) Distribution of $\mathrm{Cr}, \mathrm{Zn}, \mathrm{Cu}, \mathrm{Pb}$ and $\mathrm{C}$ organic in the surface sediments of Northern Euboikos Bay, Greece, Heavy Metals in the Environment, Athens, 2, 356-358.

56. Voutsinou-Taliadouri F. (1989) Heavy metals in surface sediments from a semi-enclosed embayment of the Ionian Sea: Amvrakikos Gulf, Greece, Heavy Metals in the Environment, Geneva, 2, 367-370.

57. Voutsinou-Taliadouri F. and Satsmadjis J. (1982) Concentration of some metals in East Aegean sediments, Rev. Int. Oceanogr. Med., 113-114, 71-76.

58. Yazkan M., Ozdemir F. and Gölukcu M. (2002) Cu, Zn, Pb and Cd content in some fish species caught in the Gulf of Antalya, Turkish Journal of Veterinary and Animal Sciences, 26(6), 1309-1313.

59. Zyadah M. and Chouikhi A. (1999) Heavy metal accumulation in Mullus barbatus, Merluccius merluccius and Boops boops fish from the Aegean Sea, Turkey, International Journal of Food Sciences and Nutrition, 50, 429-434. 